Book Review

\title{
Aguas, Jove Jim S. Person, Action and Love: The Philosophical Thoughts of Karol Wojtyla (John Paul II). ${ }^{1}$
}

Jovito V. Cariño

$\mathrm{B}$ efore his elevation to the Chair of St. Peter, Karol Woityla had an active and sustained philosophic career as attested by his stint as Chair of Ethics at the Catholic University of Lublin; his graduate lectures that covered various themes and philosophers including Plato, Augustine, Aquinas, Kant, Scheler, Bentham and Hiume; not to mention his investigations on phenomenology and Thomism. His penultimate graduate lectures, in fact, on the subject matter of sexual ethics, given between 1957 to 1959, became the groundwork of his first book, Love and Responsibility. When he was appointed Vicar Capitular of Krakow, Wojtyla spent less and less time for his academic engagements save for those very rare occasions as when he took part in the Harvard Summer School in 1969 and in the International Thomistic Congress in 1974 where he drew the attention of the Jesuit Thomist Josef Pieper who in turn introduced him to an eminent professor of Regensburg, Josef Ratzinger, the future Benedict XVI. Despite, however, his intense pastoral preoccupations, Wojtyla found the time to put together his masterpiece Person and Act, later to be called The Acting Person. The book was the product of Wojtyla's attempt to marry the Aristotelian-Thomistic notion of person to Schelerian theory of consciousness. Stated philosophically, it was a project aimed at overcoming the Cartesian bent of phenomenology by restating its inherent unity with the very objects of thought. His intellectual engagements, however, had to take the back seat when he was elected to the papacy in 1978 and eventually became a leading global figure of exceptional charisma and influence that was felt and appreciated even beyond the realm of the Catholic Church. John Paull II became such a towering figure it might not be too inaccurate to say that his pastoral gains as the successor of St. Peter easily eclipsed the contributions of the abruptly interrupted philosophic career of Karol Wojtyla.

${ }^{1}$ Manila: UST Publishing House, 2014. 327 pp.

(c) 2017 Jovito V. Cariño

http://www.kritike.org/journal/issue 20/carino1 june2017.pdf

ISSN 1908-7330

$(c c)$ BY-NC-ND 


\section{PERSON, ACTION AND LOVE}

What Aguas did in his first major publication was precisely to restore Wojtyla in his rightful place among the best contemporary minds in the Catholic philosophic tradition and it is rather fortuitous that his book came out on the very year that the latter, together with John XXIII, was canonized. Observers commonly underrate Wojtyla as a marginal intellectual figure owing to his subdued presence in the mainstream philosophic debates of his time. Nothing, however, is farther from the truth, and Aguas amply demonstrates why. Person, Love, Action is a careful, thoughtful retrieval of Wojtyla's fundamental insights. There are indeed philosophers who acquire their reputation on account of the questions they leave unanswered like Descartes, Hume, or Kant. And there are those who make a name by their perseverance not to leave any possible answer unsaid. Wojtyla belongs to the second type of thinkers. His legacy lies not so much on the new problems he poses but on the new perspectives he introduces and brings to bear on problems, either old and new. This is fairly evident in Wojtyla's attempt to bring phenomenology, existentialism, and Thomism into harmonious discourse to come up with an ethical theory or better yet, a philosophical anthropology that is simultaneously phenomenological, existential, and Thomist without necessarily becoming a mere extension of any of these strands. As pointed out by Aguas in his description of Wojtyla's philosophical anthropology: "The understanding of man is grounded on the interrelation of being and consciousness and this interrelation serves as the basis for us to build on the ground of the experience of man our conception of person and action. The stepping stone of Wojtyla in his investigation therefore is the experience of man. And by starting from this point, he is able to avoid the controversy between subjectivism and objectivism, he starts beyond the dichotomy of being and consciousness."

Wojtyla's intervention comes at a crucial time when Catholic philosophy was in a dire need for an appropriate grammar that would articulate its fundamental philosophical tenets without compromising its essential content. The solution came with Wojtyla's ingenious reconciliation of the new horizon offered by phenomenology and the appraisal of the human person espoused by Catholicism via the philosophy of Thomas Aquinas. In his book, as pointed out earlier, Aguas emphasizes that Wojtyla's maneuver involves more than just a happy interface between two seemingly opposed thought systems. He finds in it instead a creative attempt to transcend the tension between the subjective bent of consciousness and the traditional Catholic metaphysical position that sustains and is sustained by Aquinas' philosophical anthropology. Such endeavor results eventually not so much in a superimposition of one domain over the other but in a new hermeneutic space that makes it possible for consciousness to recognize the limits of its subjective dimension as it begins to recognize its constitutive 
aspect, that is, the "constitutive aspect of the dynamic structure, that is, of the acting person."

It should be noted at this point that Wojtyla is neither the first nor the only Catholic thinker that attempts to bring phenomenology and Thomism to a fusion. Before him, there was Edith Stein (the future St. Teresa Benedicta of the Cross whose canonization would be presided by no less than John Paul II himself) who early on had explored this possibility after veering away from Husserlian phenomenology due to its transcendental leanings. Stein found in Aquinas an ontology that could mitigate both the inadequacies and excesses of a philosophy dogged down by the problems of a selfindulgent consciousness. What Stein failed and Wojtyla succeeded to work out was a systematic treatment of such fusion's theoretical possibility. This is something not yet apparent in Wojtyla's first book, Love and Responsibility, owing to its pedagogical and apologetic orientation. It would not be until The Acting Person that its foundation and structure would acquire their fuller form. As reported by Aguas: "The outcome would be what Wojtyla would regard years later as a way of doing philosophy that 'synthesized both approaches,' namely, the metaphysical realism of Aristotle and Thomas Aquinas and the sensitivity to human experience of Max Scheler' phenomenology."

And, I suppose, this is where the edge of a seasoned doer of philosophy like Aguas would come in, for I see no other way of showing the depth and breadth of Wojtyla's accomplishment as a philosopher except through an actual rehearsal of the latter's philosophic itinerary which cuts across various philosophical systems and episodes of the history of philosophy. Wojtyla's nuanced handling of Aquinas' insights, for example, can easily weigh down someone unless he has the skill and the appropriate comfortability with the arcane medieval system of thought. Aguas, thankfully, has both, enabling him thus to re-package an otherwise difficult treatise into a material worthy of Wojtyla's name.

Department of Philosophy, University of Santo Tomas, Philippines

(C) 2017 Jovito V. Cariño

http://www.kritike.org/journal/issue 20/carino1 june2017.pdf

ISSN 1908-7330

(c) BY-NC-ND 